\title{
Can anatomical and physiological characters predict plant adaptation on tin-mined land in Bangka Island?
}

\author{
E. Nurtjahya Universitas Bangka Belitung, Indonesia \\ Robika Universitas Bangka Belitung, Indonesia
}

Dorly Institut Pertanian Bogor, Indonesia

\begin{abstract}
In the last decade, a handful of local tree species were planted on the tin-mined land in Bangka Island to support biodiversity and to meet the economical need of the local people in post tin-mining era. Exotic species have been used predominantly since revegetation was mandatory in Bangka Belitung islands in 1992. Some leaf anatomical and root physiological characters of five year saplings of ubak (Syzygium grande), penaga (Calophyllum inophyllum), and leban planted in unmined land and tin-mined land were studied to enrich local tree selection. Stomatal density, epidermal cells thickness, cuticle thickness, palisade and spongy mesophyll thickness, root conductivity and root conductivity ratio, chlorophyll and nitrogen contents, and plant height, stem diameter and canopy area of those species were measured. Based on the anatomical and physiological measurements, the best adapted species was V. pinnata, followed by C. inophyllum and then S. grande. Morphological measurements, however, show that the best performance was $\mathrm{S}$. grande, $\mathrm{C}$. inophyllum and $\mathrm{V}$. pinnata. Further study is required to validate this result by assessing the transpiration rate of those species that are grown on mined and unmined lands and by measuring the free proline concentration.
\end{abstract}

\section{Introduction}

Bangka is the largest tin producing island in Indonesia, contributing $40 \%$ of the world's demand for tin (ASTIRA, 2005). Tin-mining leaves behind disturbed land, ex tin-mining ponds, and damages natural drainage and habitats. The total area of mine-impacted lands, including other marginal lands in the province is 1,642 ha (Metro Bangka Belitung, 2008); or even more than 5,000 ha if this includes the illegally re-mined area in the revegetated area (Nurtjahya, 2008), and in pepper and rubber plantation (Nurtjahya et al., 2008a).

Sand tin tailings may have $95 \%$ sand, C-organics less than $2 \%$, cation exchange capacity less than 1.0. Its soil temperature may reach $45^{\circ} \mathrm{C}$ (Nurtjahya et al., 2008b), and its phosphate solubilising bacteria and arbuscular mycorrhizal fungi readings were reported as low (Nurtjahya et al., 2009).

Revegetation on tin-mined land showed that higher planting density and top soil addition gave the highest survival rate as the higher density might supply more organic matter, as well as supporting more suitable soil and air temperature, and soil humidity. Highest planting density also gave highest cover and litter production was significantly influenced by legume cover crops (Nurtjahya et al., 2008c). The higher tendency of some soil fauna population at higher plant density may be due to the improved microclimate, especially humidity (Nurtjahya, 2008). The Collembolan population significantly increased along with the age of revegetated tinmined land using Acacia mangium Willd. (Fabaceae) (Nurtjahya et al., 2007).

Reliance on natural succession to restore sand tin tailings without any human aid can be very slow (Mitchell, 1959; Nurtjahya et al., 2009). A number of exotic species have been widely used in rehabilitation programs since 1992 but ecological caution suggests that it is unwise to continue to rely on such a limited species mix for all future rehabilitation efforts (Lamb and Tomlinson, 1994), as they may inhibit natural re-colonisation. Therefore, the use of exotic species is gradually being left behind. On the other hand, the use of local species has not been maximally developed to revegetate tin-mined lands in Bangka Island.

Selection of native tree species has been guided by information from natural succession on tin-mined land observation (Nurtjahya et al., 2009), morphological performance of some local tree species planted on 
tin-mined sites (Nurtjahya et al., 2008b), vegetation types (Roemantyo et al., 2004), xerophytic species (Khemnark and Sahunalu, 1988) and by lists of plant invaders in revegetated tin-mined land (Setiawan, 2003; Latifah, 2000). As revegetation should support biodiversity and meet the economical need of local people in the post tin-mining era, local tree species selection becomes more important. The study of anatomical and physiological characters is therefore needed. Five year saplings of three native tree species, i.e. ubak (Syzygium grande (Wight) Walp. - Myrtaceae), penaga (Calophyllum inophyllum L. - Clusiaceae), and leban (Vitex pinnata L. - Verbenaceae) were planted in tin-mined and unmined land, but can their anatomical and physiological characters predict plant adaptation on mined land?

\section{Methodology}

\subsection{Study site}
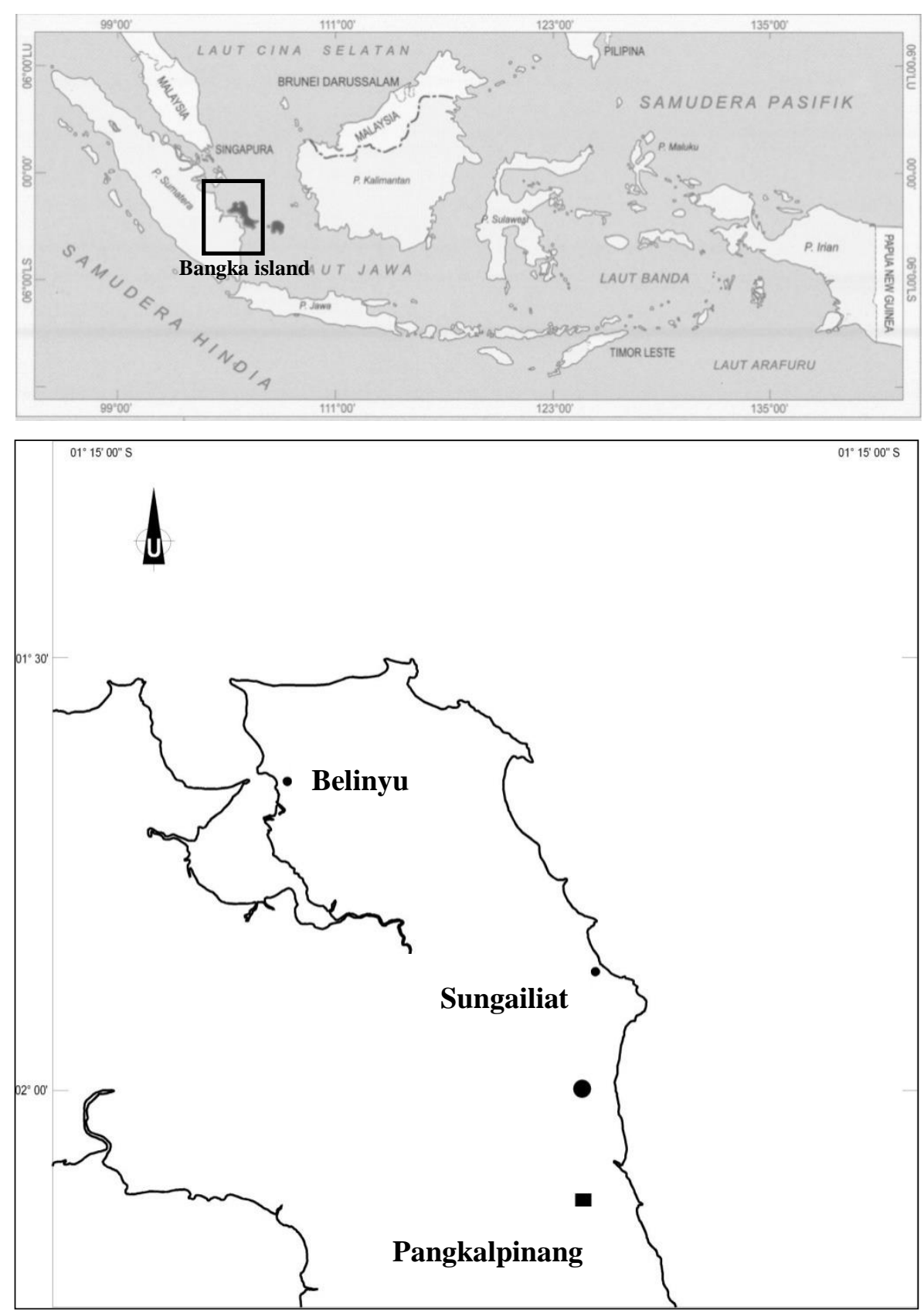

Figure 1 Study site (•) in the north east of Bangka Island 
The two hectare revegetated tin-mined land located at Riding Panjang, Bangka Island, Indonesia (lat. 01059'53.46”S; long. 106o06'45.32”E; $30 \mathrm{~m}$ asl.) and 0.02 ha unmined land (lat. 01051'49.0"'S; long. 106007 '09.5'E; $30 \mathrm{~m}$ asl.) were selected for the trial (Figure 1). Mean annual rainfall (1996-2005) was $2,408 \mathrm{~mm}$, and temperature ranges were from $23.8-31.5 \mathrm{oC}$ with an average of $26.8 \mathrm{oC}$ (Pangkalpinang Meteorology Station, 2006).

\subsection{Plant tissue sampling}

Leaf and root samples of five-year old saplings of ubak (Syzygium grande (Wight) Walp. - Myrtaceae), penaga (Calophyllum inophyllum L. - Clusiaceae), and leban (Vitex pinnata L. - Verbenaceae) were collected from mined and unmined sites. Leaf samples of each species were collected from three branches of the three trees. For paradermal cut preparation, one leaf from the fourth position from apex was taken and fixed with $70 \%$ alcohol. For transversal cut preparation, one leaf from the third position from apex was taken and cut $10 \times 10 \mathrm{~mm}$ and fixed in a FAA solution (5:5:90 of formaldehyde, asetate acid glacial, and 70\% alcohol), in plastic bottle for two days. Primary root tip samples were transversally cut $\pm 0.5 \mathrm{~cm}$. Root samples were collected from three individuals, each species as a repetition. Those samples were put in plastic bottles, and fixed in FAA solution for four days.

\subsection{Plant tissue preparation}

The paradermal cut was prepared in a semi-permanent slide and coloured with $1 \%$ safranine according to the wholemount method by Sass (1951) through the following steps: fixation in 70\% alcohol, washed and soaked in aquadest, softened with $30 \% \mathrm{HNO}_{3}$ solution for 24 hours, washed with aquadest, sliced with a knife, chlorophyll extraction with chlorine solution in for a few minutes and then washed with aquadest, coloured with $1 \%$ safranine for 3-5 minutes, and finally covered with cover glass with $10 \%$ glycerine.

The transversal cut was prepared according to the paraffin method by Johansen (1940), using a series of Johansen tertiary butyl alcohol (TBA) solution as dehydrant through the following steps: fixation in FAA solution for four days, washed with $70 \%$ alcohol for 30 minutes (twice) and then kept in $70 \%$ alcohol for further process, dehydrated and cleared in 50\% alcohol for one hour (twice), and then soaked in a series of Johansen I - VII solution, infiltrated with TBA solution and paraffin and frozen paraffin for 1-4 hours at room temperature, and then put in the oven at $58 \mathrm{oC}$ for 12 hours and changed the paraffin three times every six hours the next morning, and finally kept in the oven at $58 \mathrm{oC}$. The material was softened by soaking in a Gifford solution for one week, and sliced with a rotary microtome at $9 \mu \mathrm{m}$, then coloured with $2 \%$ safranine in water and $0.5 \%$ fast green in $95 \%$ alcohol, and finally covered with entellan media and covered with cover glass.

Chlorophyll analysis was conducted according to spectroscophy (Sims and Gamon, 2002) and the absorbance was measured with $652 \mathrm{~nm}$. Nitrogen content was analysed with Kjehdal method.

\subsection{Plant growth}

Plant height, stem diameter at diameter at breast height (dbh) and the canopy area of five-year old S. grande, $C$. inophyllum, and $V$. pinnata saplings grown on mined and unmined sites were measured. Four individuals per species were randomly selected. Stem and canopy diameter were measured twice: the longest and the shortest ones.

\subsection{Data collection and analysis}

A student test was run to compare every variable measured from plants grown in mined and unmined sites. Leaf anatomy variables, i.e. stomatal density, stomatal length and width, leaf thickness, palisade thickness, spongy thickness, epidermal thickness, cuticle thickness, and leaf tissue ratio (palisade thickness divided by leaf thickness) were measured. Root conductivity is the total area of xylem bundles, and the root conductivity ratio is the root conductivity divided by cross-section of root area. 


\section{$3 \quad$ Results}

\subsection{Leaf anatomical structure}

Ubak leaf ( $S$. grande) and penaga leaf ( $C$. inophyllum) have hypostomatic type or are abaxial, whereas leban leaf ( $V$. pinnata) has anisositic type stomata. The stomatal density of each three species was not significantly different between mined and unmined ones, but stomatal densities on mined sites were greater than those on unmined sites, and the stomatal density of $V$. pinnata leaf grown on mined site $\left(592.66 \mathrm{~mm}^{-2}\right)$ was double than that on an unmined site $\left(290.98 \mathrm{~mm}^{-2}\right)$ (Table 1) (Figure 2a).

The leaf thickness of the $S$. grande and $C$. inophyllum leaves were not significantly different between mined and unmined ones, but that of the $V$. pinnata leaf on mined sites was greater and significantly different from that of unmined sites. Palisade thickness of the $S$. grande leaf was not significantly different between mined and unmined ones, but those of the $C$. inophyllum and $V$. pinnata leaves on mined sites were greater and significantly different from those on unmined sites. The spongy tissue thickness of $S$. grande and C. inophyllum leaves were not significantly different between mined and unmined ones, but that of $V$. pinnata leaf on mined sites was greater and significantly different from that of unmined sites (Figure 2b).

The upper epidermal thickness of each three species was not significantly different between mined and unmined ones, but the epidermal thickness of $C$. inophyllum and $V$. pinnata leaves on mined sites were greater than those on unmined sites. The lower epidermal thickness of $S$. grande grown on mined site was bigger and significantly different from those on unmined site, whereas those $C$. inophyllum and $V$. pinnata leaves were not significantly different.

Both upper and lower cuticle thickness of each three species grown on mined sites were greater than those grown on unmined site. Only the upper cuticle of $C$. inophyllum showed significant difference between the mined and unmined sites.

Table 1 Stomatal density, leaf thickness, palisade thickness, spongy tissue thickness, epidermal thickness, and cuticle thickness of five-year old $S$. grande, $C$. inophyllum, and V. pinnata saplings grown on tin-mined and unmined sites

\begin{tabular}{|c|c|c|c|c|c|c|c|c|c|c|}
\hline & \multirow[b]{2}{*}{ Unit } & \multicolumn{3}{|c|}{ S. prande } & \multicolumn{3}{|c|}{ C. pnophyllum } & \multicolumn{3}{|c|}{$V \cdot$ pinnata } \\
\hline & & Mined & & Unmined & Mined & & Unmined & Mined & & Unmined \\
\hline Stomatal density & $\mathrm{mm}^{-2}$ & 583.96 & & 505.03 & 302.62 & & 298.87 & 592.66 & & 290.98 \\
\hline Leaf thickness & $\mu \mathrm{m}$ & 397.78 & & 373.33 & 305.83 & & 266.67 & 166.04 & $*$ & 111.18 \\
\hline Palisade thickness & $\mu \mathrm{m}$ & 134.93 & & 115.14 & 70.07 & 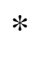 & 50.28 & 76.04 & $*$ & 44.72 \\
\hline Spongy tissue thickness & $\mu \mathrm{m}$ & 306.39 & & 270.56 & 237.29 & & 180.49 & 58.68 & $*$ & 42.08 \\
\hline Upper epidermal thickness & $\mu \mathrm{m}$ & 11.76 & & 12.22 & 17.78 & & 17.68 & 15.49 & & 12.29 \\
\hline Lower epidermal thickness & $\mu \mathrm{m}$ & 9.65 & $*$ & 8.26 & 15.35 & & 15.42 & 8,94 & & 8.75 \\
\hline Upper cuticle thickness & $\mu \mathrm{m}$ & 5.83 & & 5.31 & 4.44 & $*$ & 3.61 & 3.25 & & 2.08 \\
\hline Lower cuticle thickness & $\mu \mathrm{m}$ & 4.25 & & 3.85 & 2.39 & & 1.92 & 2.25 & & 2.03 \\
\hline
\end{tabular}

Asterix (*) indicates that means was significantly different between treatments $(0.05)$

The increase of stomatal density on mined sites compared to those on unmined sites was also observed for Trema orientalis and Commersonia bartramia on tin-mined site (Juairiah et al., 2005). These findings are similar to Willmer's (1983) in that the plants grown in dry areas that have abundant sunlight have bigger stomatal density compared to those in humid and sheltered conditions (Heckenberger et al., 1998; Willmer, 1983; Sutcliffe, 1979). The increase of stomatal density is to compensate for the decrease of leaf area of those plants that the need to reduce transpiration because of water stress (Sutcliffe, 1979). Besides, water stress reduces stomatal development as the condition hampers the differentiation of guard cells (Ciha and Brun, 1975). Similar findings are also reported in some soybean (Glycine max) genotips (Poejiastuti, 1994), Vinca rosea (Sukarman et al., 2000), and Lotus creticus (Banon et al., 2004). On the other hand, the stomatal 
density of plants which have stomatal density on a mined site lower or similar to those on undisturbed site show their adaptation to water stress (Poejiastuti, 1994; Dobrenz et al., 1969).

The thicker palisade cells of plants grown on water stress environment might show their tolerance to water stress (Poejiastuti, 1994). Palisade cells enlarged their cells in a water stress environment (Poejiastuti, 1994) and the chloroplast increase of those in a water stress environment might take place in enlarged palisade cells.

In higher light intensity, palisade cells are longer and have more than two layers (Salisbury and Ross, 1995; Taiz and Zeiger, 2002). Shields (1950) mentioned that palisade thickness relates to a leaf's greater tolerance to water stress. Leaves exposed to full sunlight are relatively thicker and have more layers at the mesophyll zone (Dickison, 2000). The internal leaf changes may relate to photosynthesis efficiency. A thicker cuticle supports the plant from water stress (Imaningsih, 2006). Thicker leaf indicates xerophytes (Fahn, 1992). Thicker epidermal cells may also prevent leaves from experiencing excessive sunlight and help control transpiration. As shown in Table 1, each species experiences different adaptation to water stress on mined sites.

\subsection{Root conductivity}

The average number of root xylem diameter, number of root xylem bundles and root diameter of all three species grown on mined sites were smaller than those at unmined sites (Table 2). Root xylem diameter and the number of root xylem bundles of $S$. grande grown on mined sites were significantly different from those of unmined sites. The root diameter of $V$. pinnata was significantly different from that of unmined sites (Figure 2c). As the root xylem diameter has a positive correlation with water conductivity (Eshel et al., 2000), reduced root xylem diameter appears to be a strategy to reduce water conductivity in a water limited condition. Banon et al. (2004) mentioned that water stress on L. creticus causes the increase of root and shoot xylem density. The increase of root xylem density and diameter might be one response to water stress. Less water availability may be followed with an increased number and diameter of root xylem bundles.

The root conductivity and root conductivity ratio of $V$. pinnata grown on a mined site were bigger than those on an unmined site; only the root conductivity ratio of $C$. inophyllum at the unmined site was slightly below that from the mined one (Table 2). Although there was not a significant difference between mined and unmined readings of any native tree species, root conductivity of $S$. grande on a mined site was nearly one fourth of that on an unmined one, whereas $C$. inophyllum on mined sites was three quarters and $V$. pinnata were almost half of those on unmined sites. Among the three species, the root conductivity ratio of $S$. grande on mined site was the most reduced.

The horizontal growth of root on a mined site seems to be reduced, and the high soil temperature was among the main factors influencing (Fitter and Hay, 1991) as the tin tailing temperature may reach 45oC (Nurtjahya et al., 2008c), and it is possible that more energy was used to support the vertical growth of root on a nutrient-limited site (Goldsworthy and Fisher, 1984). In mined sites, the xylem diameter reduction is possibly to keep transpiration low.

Table 2 Root xylem diameter, root xylem bundles, root diameter, root conductivity and root conductivity ratio of five-year old $S$. grande, $C$. inophyllum, and $V$. pinnata saplings grown on tin-mined and unmined sites

\begin{tabular}{|c|c|c|c|c|c|c|c|c|c|}
\hline & \multirow[b]{2}{*}{ Unit } & \multicolumn{3}{|c|}{ S. grande } & \multicolumn{2}{|c|}{ C. inophyllum } & \multicolumn{3}{|c|}{$V \cdot$ pinnata } \\
\hline & & Mined & & Unmined & Mined & Unmined & Mined & & Unmined \\
\hline Xylem diameter & $\mu \mathrm{m}$ & 49.2 & $*$ & 71.9 & 40.5 & 41.0 & 52.9 & & 71.5 \\
\hline Xylem bundles & & 59.3 & $*$ & 103.7 & 41.3 & 52.7 & 83.3 & & 123.3 \\
\hline Root diameter & $\mu \mathrm{m}$ & 713.3 & & 893.3 & 720.0 & 860.0 & 616.7 & $*$ & 923.3 \\
\hline Root conductivity & $\mu \mathrm{m}^{2}$ & $112,592.6$ & & $420,401.7$ & $52,998.8$ & $69,498.1$ & $298,518.1$ & & $669,247.4$ \\
\hline Root conductivity ratio & & 0.28 & & 0.67 & 0.13 & 0.12 & 0.61 & & 0.74 \\
\hline
\end{tabular}

Asterix (*) indicates that means was significantly different between treatments $(0.05)$ 


\subsection{Chlorophyll and nitrogen contents}

The chlorophyll and nitrogen contents of $S$. grande leaves grown on mined sites were greater than those on unmined sites, whereas the chlorophyll and nitrogen contents of $C$. inophyllum and $V$. pinnata leaves grown on mined sites were smaller than those on unmined sites, with significant difference shown on $V$. pinnata (Table 3).

The lower chlorophyll and nitrogen contents of $C$. inophyllum and $V$. pinnata leaves grown on mined sites may be due to limited nitrogen on mined sites, which may be as low as $0.01 \%$ (Nurtjahya et al., 2009). Prsa et al. (2007) mentioned the positive correlation between the available soil nitrogen and chlorophyll, and the nitrogen contents on leaves. The slightly higher chlorophyll and nitrogen contents on $S$. grande leaves grown on mined site may be due to the intra-specific competition on unmined site.

Table 3 Chlorophyll and nitrogen contents of five-year old S. grande, C. inophyllum, and V. pinnata saplings grown on tin-mined and unmined sites

\begin{tabular}{|c|c|c|c|c|c|}
\hline & \multicolumn{3}{|c|}{ Chlorophyll $\left(\mu \mathrm{mol} .100 \mathrm{~cm}^{-2}\right)$} & \multicolumn{2}{|c|}{ Nitrogen $(\%)$} \\
\hline & Mined & & Unmined & Mined & Unmined \\
\hline S. grande & 6.86 & & 6.72 & 1.20 & 1.16 \\
\hline C. inophyllum & 2.29 & & 5.02 & 1.14 & 1.15 \\
\hline$V \cdot$ pinnata & 4.57 & $*$ & 5.77 & 1.59 & 2.20 \\
\hline
\end{tabular}

Asterix $(*)$ indicates that means was significantly different between treatments $(0.05)$

\subsection{Plant growth}

Five years after planting, $S$. grande showed a much wider canopy area $\left(7.64 \mathrm{~m}^{2}\right)$ compared to the canopy area of $C$. inophyllum $\left(2.03 \mathrm{~m}^{2}\right)$ and that of $V$. pinnata $(3.28 \%)$. The plant height and stem diameter of $S$. grande grown on mined sites were also higher than the other two species (Table 4). The effect of mined soil on plant growth was clearly shown with $S$. grande and $C$. inophyllum, however its effect on $V$. pinnata was not clearly shown due to interspecific and intraspecific competition on the unmined sites.

The growth rate and the survival rate of those species were not different since the first year (Nurtjahya et al., $2008 \mathrm{~b}$ ). At the end of year one, the canopy area of $S$. grande was $0.25 \mathrm{~m}^{2}$ and its survival was $90.2 \%$; the canopy area of $C$. inophyllum was $0.13 \mathrm{~m}^{2}$ and its survival rate was $99.3 \%$, and the canopy area of V. pinnata was $0.07 \mathrm{~m}^{2}$ and its survival rate was $68.8 \%$ (Nurtjahya et al., 2008b).

Based on plant growth, the best performance was from $S$. grande, followed by $C$. inophyllum and V. pinnata.

Table 4 Plant height, stem diameter and cover area of five-year old S. grande, C. inophyllum, and $V$. pinnata saplings grown on tin-mined and unmined sites

\begin{tabular}{lcccccc}
\hline & \multicolumn{2}{c}{ Height $(\mathbf{m})$} & \multicolumn{2}{c}{ Stem Diameter $(\mathbf{m m})$} & \multicolumn{2}{c}{ Cover Area $\left(\mathbf{m}^{2}\right)$} \\
& Mined & Unmined & Mined & Unmined & Mined & Unmined \\
\hline S. grande & 5.4 & 6.88 & 66.8 & 62.4 & 7.64 & 2.98 \\
C. inophyllum & $3.43^{*}$ & 6.5 & $28.6^{*}$ & 110.6 & 2.03 & 6.64 \\
V. pinnata & 1.35 & 1.55 & 44.9 & 35.8 & 3.28 & 1.45 \\
\hline \multicolumn{4}{r}{ Asterix (*) indicates that means was significantly different between treatments (0.05) }
\end{tabular}



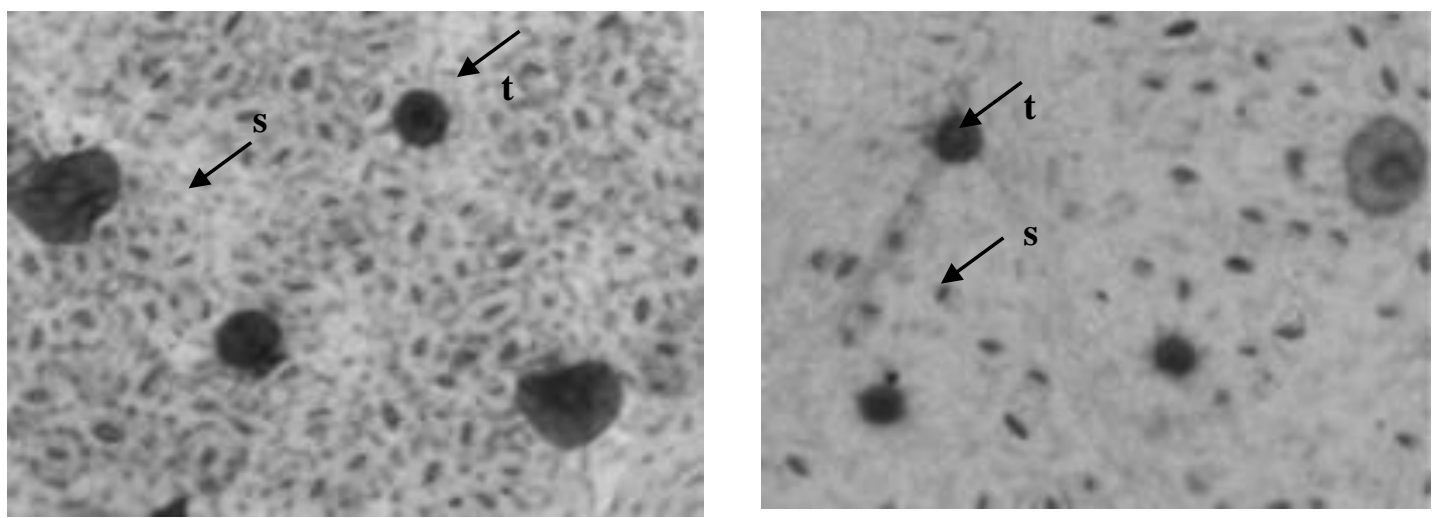

Figure 2a Lower paradermal of $V$. pinnata , left $=$ mined; right $=$ unmined site; $\mathrm{s}=$ stomata; $t=$ trichome; note: double of stomatal density on the left
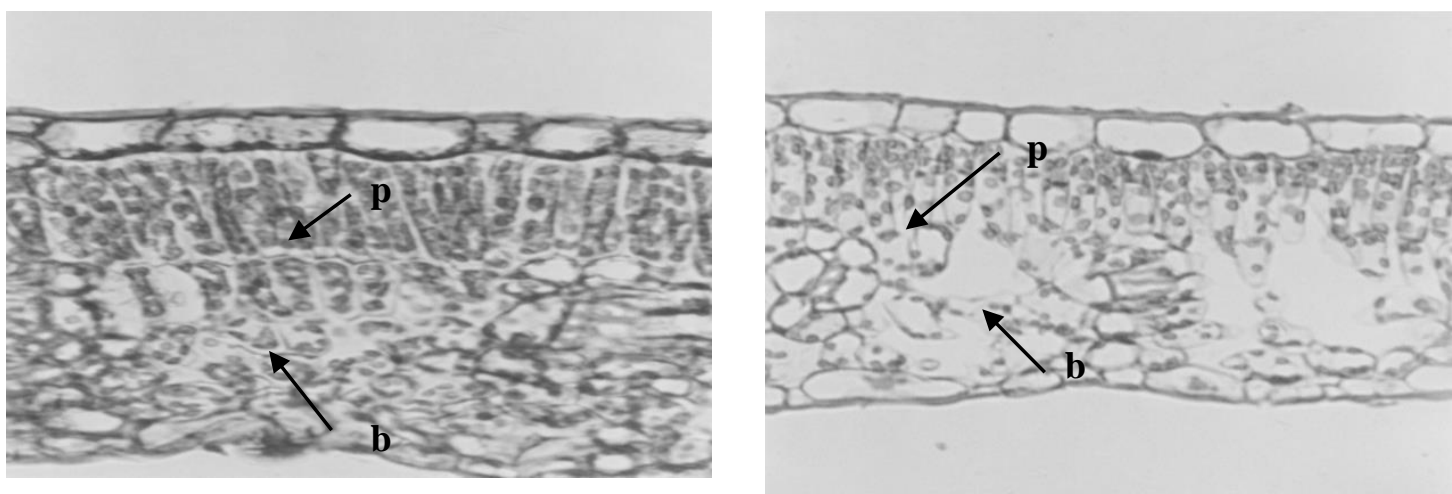

Figure 2b Leaf transversal of $V$. pinnata, left $=$ mined; right $=$ unmined site; $p=$ palisade tissues; $b=$ spongy tissues; note: longer and nearly double of palisade tissues thickness on the left
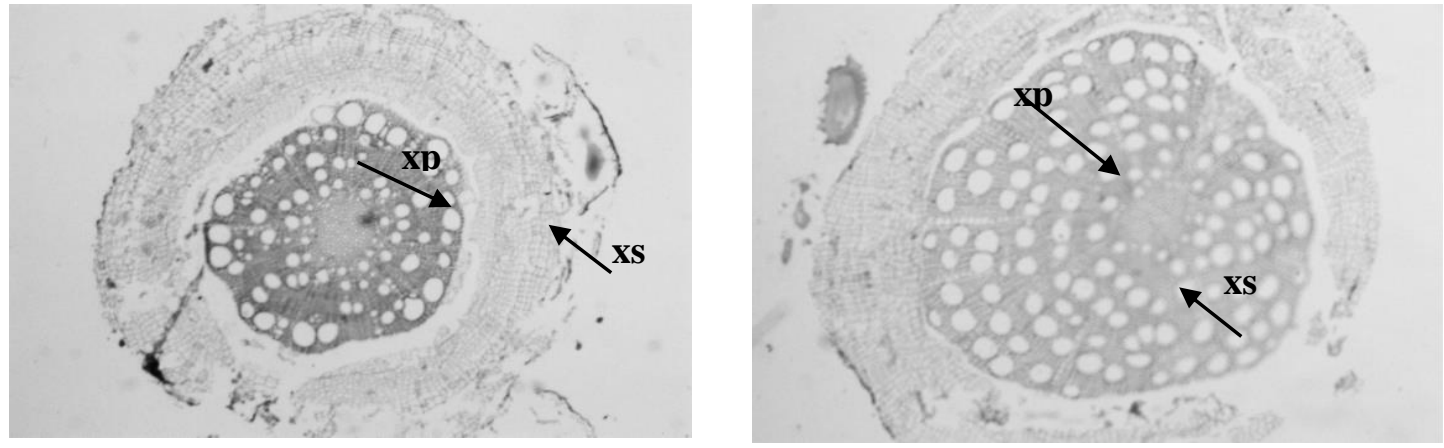

Figure 2c Root cross section of $V$. pinnata , left = mined; right = unmined site; $x p=$ primary $x y l e m$; xs = secondary xylem; note: nearly 30 percent reduced xylem diameter, xylem bundles, and root diameter on the left

\subsection{Anatomical and physiological versus morphological characters}

Adaptation to a dry area that has abundant sunlight was shown by the bigger stomatal density (Heckenberger et al., 1998; Willmer, 1983; Sutcliffe, 1979) to compensate for the decrease of leaf area of those that suffer water stress and need to reduce transpiration (Sutcliffe, 1979). Leaves exposed to full sun light are relatively thicker and have more layers at the mesophyll zone (Dickison, 2000), and the internal leaf changes may relate to photosynthesis efficiency. The thicker palisade cells of plants grown in water stress environments 
show their tolerance (Poejiastuti, 1994; Shields, 1950). Palisade cells show longer and more layers (Salisbury and Ross, 1995; Taiz and Zeiger, 2002). The thicker cuticle, which indicates xerophytes (Fahn, 1992), supports the plants during water stress conditions (Imaningsih, 2006). The thicker epidermal cells prevent leaves from excessive sunlight, as well as help control transpiration.

Root xylem diameter has a positive correlation with water conductivity (Eshel et al., 2000), so that the reduced root xylem diameter seems to be a strategy to reduce water conductivity in a water limited condition. The horizontal growth of root on mined site seems to be reduced, and a high soil temperature was among the main factors influencing (Fitter and Hay, 1991) the growth pattern, as the tin tailing temperature may reach $45^{\circ} \mathrm{C}$ (Nurtjahya et al., 2008c), and it is possible that more energy was used to support the vertical growth of the root on a nutrient-limited site (Goldsworthy and Fisher, 1984). In a mined site, the xylem diameter reduction is possibly a response to keep transpiration low.

Prsa et al. (2007) mentioned the positive correlation between the available soil nitrogen and chlorophyll and the nitrogen contents on leaves.

Based on the anatomical and physiological measurements, the most adapted species was $V$. pinnata, followed by $C$. inophyllum and the least was $S$. grande. However, $S$. grande showed its best performance in plant height, stem diameter, and canopy area, while $C$. inophyllum came to second and the last was $V$. pinnata. The survival rate of those species from year one through to year five validated the plant growth data (Nurtjahya et al., 2008b).

This finding shows that the anatomical and physiological characteristics need to be added to the other parameters, such as transpiration rate, and free proline concentration. The latter could identify the sensitivity or tolerance to water stress (Sukarman et al., 2000).

\section{Conclusions}

Based on the anatomical and physiological measurements, the most adapted species was $V$. pinnata, followed by $C$. inophyllum and then $S$. grande. Based on data on plant height, stem diameter, canopy area, and survival rate, $S$. grande was the best performer, followed by $C$. inophyllum and then $V$. pinnata. This finding shows that the anatomical and physiological characteristics studied need to be added to other parameters, such as transpiration rate and free proline concentration to understand which plant species would perform better on mined sites.

\section{Acknowledgements}

The authors gratefully acknowledge part funding of this research by Bantuan Corporate Social Responsibility of PT Timah (Persero) Tbk., Bangka. Special thanks to the reviewers for their valuable comments on the manuscript.

\section{References}

ASTIRA (2005) Asosiasi Tambang Timah Rakyat. Tambang Rakyat Potensi Terabaikan. Makalah seminar penambangan timah di Pangkalpinang.

Banon, S., Fernandez, J.A., Franco, J.A., Torrecillas, A., Alarcon, J.J. and Sanchez-Blanco, M.J. (2004) Effects of Water Stress and Night Temperature Preconditioning on Water Relations and Morphological and Anatomical changes of Lotus creticus Plants, Scientia Horticulturae 101, pp. 333-342.

Ciha, A.J. and Brun, W.A. (1975) Stomatal Size and Frequency in Soybeans, Crop Science 15, pp. 309-313.

Dickison, W.O. (2000) Integrative Plant Anatomy, Tokyo, Academic Press.

Dobrenz, A.K., Wright, L.N., Humprey, A.B., Massergale, M.A. and Kneebone, W.R. (1969) Stomatal density and its relationship to water use efficiency of blue panigrass (Panicum antidotale Retz.), Crop Science 9, pp. 354-357.

Eshel, A., Shick, I. and Waisel, Y. (2000) The Efficiency of The Water Conducting System of Tomato Roots, A. Stokes (editor), Kluwer Academic Publishers, Dordrecht, pp. 371-375.

Fahn, A. (1992) Anatomi Tumbuhan Jilid 3, Yogyakarta, Gadjah Mada University Press, 943 p.

Fitter, A.H. and Hay, R.K.M. (1991) Fisiologi Lingkungan Tanaman,Yogyakarta, Gajah Mada University Press. Terjemahan dari: Environmental Physiology of Plants, 421 p.

Goldsworthy, P.R. and Fisher, N.M. (1984) Fisiologi Tanaman Budidaya Tropik, Yogyakarta: Gadjah Mada University Press. 
Heckenberger, U., Roggatz, U. and Schurr, U. (1998) Effect of Drought Stress on The Cytological Status in Ricinus communis, Journal of Experimental Botany 49(319), pp. 181-189.

Imaningsih, W. (2006) Studi Banding Sifat Ketahanan Struktural Terhadap Kekeringan antara Varietas Padi Sawah dan Padi Gogo Berdasarkan Struktur Anatomi Daun, Bioscientiae 3, pp. 47-58.

Johansen, D.A. (1940) Plant Microtechnique, New York: McGraw-Hill Book Company Inc.

Juairiah, L., Nurtjahya, E., Prawitasari, T. and Dorly (2005) Konduktivitas Xilem Akar dan Batang Tumbuhan Pionir di Lahan Pasca Penambangan Timah di Desa Sempan, Bangka, Proceeding of Seminar MIPA Nasional 2005, November 2005, Universitas Indonesia, Jakarta, 4 p.

Khemnark, C. and Sahunalu, P. (1988) Revegetation trials for tin mine tailings reclamation in Thailand, Proceedings of Regional Workshop on Ecodevelopment Process for Degraded Land Resources in Southeast Asia, S. Adisoemarto (ed), August 1988, Bogor.

Lamb, D. and Tomlinson, M. (1994) Forest rehabilitation in the Asia-Pasific region: past lessons and present uncertainties, Journal of Tropical Forest Science 7, pp. 157-170.

Latifah, S. (2000) Keragaan pertumbuhan Acacia mangium Willd. pada lahan bekas tambang timah (studi kasus di areal kerja PT Timah Tbk.) (tesis, Institut Pertanian Bogor, Bogor).

Metro Bangka Belitung (2008) Edisi Khusus Bangka Goes Green, Bangka Goes Green, Pangkalpinang, Edisi Khusus.

Mitchell, B.A. (1959) The ecology of tin mine spoil heaps. Part I sand and gravel tailings, Malayan Forestry 22, pp. 111-132.

Nurtjahya, E. (2008) Revegetasi Lahan Pasca Tambang Timah dengan Beragam Jenis Pohon Lokal di Pulau Bangka, Sekolah Pascasarjana Institut Pertanian Bogor, Bogor. PhD thesis (unpublished).

Nurtjahya, E., Agustina, F. and Putri, W.A.E. (2008a) Neraca Ekologi Penambangan Timah Di Pulau Bangka - Studi kasus pengalihan fungsi lahan di ekosistem darat, Berkala Penelitian Hayati 14(1), pp. 29-38.

Nurtjahya, E., Setiadi, D., Guhardja, E., Muhadiono and Setiadi, Y. (2009) Succession on tin-mined land in Bangka Island, Blumea 54(1-3), pp. 131-138.

Nurtjahya, E., Setiadi, D., Guhardja, E., Muhadiono and Setiadi, Y. (2008b) Establishment of four local tree species for potential revegetating of tin-mined land in Bangka Island, Indonesia, Proceedings Third International Seminar on Mine Closure (Mine Closure 2008), A.B. Fourie, M. Tibbett, I.M. Weiersbye and P. Dye (eds), 14-17 October 2008, Johannesburg, South Africa, Australian Centre for Geomechanics, Perth, pp. 751-758.

Nurtjahya, E., Setiadi, D., Guhardja, E., Muhadiono and Setiadi, Y. (2008c) Revegetation of tin-mined land using various local tree species in Bangka Island, Indonesia, Proceedings of the 2008 National Meeting of the American Society of Mining and Reclamation, Richmond VA, New Opportunities to Apply Our Science, R.I. Barnhisel (ed), June 2008, ASMR, Lexington, pp. 739-755.

Nurtjahya, E., Setiadi, D., Guhardja, E., Muhadiono and Setiadi, Y. (2007) Populasi Collembola di Lahan Revegetasi Tailing Timah di Pulau Bangka, Biodiversitas 8(4), pp. 309-313.

Pangkalpinang Meteorology Station (2006) Data iklim Bangka 1996-2005, 10 p.

Poejiastuti, E. (1994) Studi Komparatif Anatomi Daun Beberapa Genotif Kedelai (Glycine max (L)) yang Peka dan Toleran terhadap Cekaman Kekeringan [skripsi], Bogor, Institut Pertanian Bogor, FMIPA.

Prsa, I., Stampar, F., Vodnik, D. And Veberic, R. (2007) Influence of Nitrogen on Leaf Chlorophyll Content and Photosynthesis of 'Golden Delicious' Apple, Acta Agriculturae Scandinavica, Section B - Plant Soil Science 57(3), pp. 283-289.

Roemantyo, Uji, T., Noerdjito, M. and Utaminingrum, H.I.P. (2004) Indonesia biodiversity information system (IBIS) case study: vegetation diversity of Bangka Island, Bangka-Biliton, Indonesia, Proceedings of International Symposium 2004 Asian Plant Diversity and Systematics, August 2004, Japan, 10 p.

Salisbury, F.B. and Ross, C.W. (1995) Fisiologi Tumbuhan, Penerbit ITB, Bandung, 343 p.

Sass, J.E. (1951) Botanical Microtechnique, Ames Lowa: The Lowa State College Press.

Setiawan, I.E. (2003) Evaluasi tingkat keberhasilan revegetasi pada lahan bekas tambang timah PT Koba Tin, Koba, Bangka Belitung. skripsi, Institut Pertanian Bogor, Bogor.

Shields, L.M. (1950) Leaf Xeromorphy as Related to Physiological and Structural Influences, Botany Review 16, pp. 399-447.

Sims, D.A. and Gamon, J.A. (2002) Relationships between Leaf Pigment Content and Spectral Reflectance Across a Wide Range of Species, Leaf Structures and Developmental Stages, Remote Sensing of Environment, 81, pp. 337-354.

Sukarman, Darwati, I. and Rusmin, D. (2000) Karakter Morfologi dan Fisiologi Tapak Dara (Vinca rosea L.) pada Beberapa Cekaman Air, Jurnal Littri 6(2), pp. 50-54.

Sutcliffe, J.F. (1979) Plants and Water 2nd edition, Edward Arnold, London.

Taiz, L. and Zeiger, E. (2002) Plant Physiology, California, The Benjamin/ Cummings Pub. Co. Inc., 559 p.

Willmer, C.M. (1983) Stomata. Longman Inc., New York, 166 p. 
